\title{
Factors Influencing Financial Institutions' Participation in Tourism Project: Case of Lagos Street Carnival.
}

\author{
J. A. Obadeyi \\ Department of Accounting \& Finance, \\ Elizade University, Ilara -Mokin, Ondo State. \\ I. O. Adesuyi \\ Department of Business Administration, \\ Elizade University, Ilara -Mokin, Ondo State. \\ Adebimpe 0. Okhiria \\ Department of Hotel Management \& Tourism, \\ Elizade University, Ilara- Mokin, Ondo State.
}

\author{
Abutu Grace N. \\ Department of Leisure \& Tourism Management, \\ Federal Polytechnic Idah, Kogi State.
}

\begin{abstract}
Tourism market is one of the vibrant non-financial sectors in Nigeria, which is challenged by non-availability of financial resources from the banking sector - one of the components of the financial system. To this extent, this paper helps to examine factors that influence financial institutions' participation in tourism project; case of Lagos street carnival. For financial institutions to participate successfully in tourism project, it requires financial support from financial institutions (banks) to showcase, promote, uplift and to financially-support the nourished culture, norms and values the people cherish; and to ensure that the beliefs of the people are not eroded by foreign culture and above all, to stimulate the economy. The primary source of data is adopted via structured questionnaire. Statistically, the estimated parameter are mean, standard deviation, and standard error $(\delta \sqrt{N})$. The responses of the respondents gathered via the questionnaire was analysed using the Statistical Package for Social Sciences (SPSS). The result shows that $56.1 \%$ of the variation of factors influencing financial institutions participation in tourism, particularly Lagos street carnival; with most of social -people participating in different tourism -related festivals (e.g. eyo, igunuko etc.), which has led to the sustainability and promotion of the societal belief. F-Statistics (4.56) is high and the $(\mathrm{P}<0.05)$ which all together indicates that overall impact of the independent variables on the dependent variable is statistically significant Also financial institutions' participation has helped to provide funds to further create awareness about the traditions, beliefs and values of Lagos indigenes, who are otherwise known as Lagosians. The study recommends that policymakers should invest immensely in tourism industry in order to enrich the socio-economic and geographical life patterns of the people in the coast area via the support of financial institutions by way of channelling funds to the tourism sub-sector in order to prevent cultural extinction. Also, government should establish institutions (ministries, departments and agencies) to strengthen and defend acquired tourism trade rights in Nigeria.
\end{abstract}

Keywords: Financial institutions, Tourism, Lagos carnival, Influencing factors, financial intermediation. 


\section{INTRODUCTION}

Tourism is a socio-economic tool for poverty alleviation, means of creating awareness about ways of life of people within a settlement and increase income generation. The search light of this paper is to stimulate the tourism sector in Nigeria via financial institutions financing influence and support such that Nigeria can also be regarded as one of the best tourism destinations as most visited by foreign travellers globally.

Tourism is a significant key for job creation, human capital development and for expanding economic opportunities globally. The present financial exposures, weak purchasing power of the local naira, credit ceilings, economic distortions, decline in the price of crude oil and economic crisis (economic recession) etc., facing Nigerian economy have strongly demanded for the needs and desires of business engagement to generate additional income and means of livelihood. As the tourism sector in Nigeria remains a catalyst for economic development and provision of employment opportunities; so also the financial institutions' ability to mobilize and channels funds to the needed sector. It is never a gainsaying that the former provides further responsibilities in the area of natural endowment, telecommunications, comparative advantages, transportation (water, land and air), embrace and respect peoples culture and belief, accommodation, nutrition as well as the financial services.

Tourism is either regarded as domestic or international for recreation, leisure with its comparative advantage (i.e. income generation, asset manage, creation of job opportunities, poverty alleviation etc.) and un-measurable implications (i.e. racism, homosexuality, arrogance, prostitution etc.); in Nigeria, tourism further centres largely on events (i.e. carnivals), due to the country's multi-ethnic groups, rain forests, savannah, waterfalls, and other natural attractions.

A healthy financial institution plays the financial intermediation role effectively making funds available to tourists at any time (24/7) the needs arise, making payment process easy (i.e. payment of hotel bills, insurance services, transport fares etc.), with comfortability at a reduced transaction costs. The financial sector ensures the mobilisation and allocation of loanable funds for production and to effectively manage liquidity system. The usual sources of funds that is made available to finance the support and development tourism sector performance is easily traced to a mutual understanding of banks (commercial banks, merchant banks, etc.), and non-banks financial institutions (pension funds administrators, insurance companies, Bureau de Change etc.), all and others have assist to meet the financial needs of business transactions.

The magnitude at which tourists manage assets is equal to achieving economic opportunity which cannot be realized without adequate finance capability from the financial institutions. Financial institutions (FIs) are institutions established to provide short, medium and long-term financial assistance to deficit industries. Though, the rate at which Central banks meet the needs of banks during cash short fall is competitively high (MPR -14\%) forcing banks to lend to individuals (i.e. including tourists) and corporate organizations at a very unbearable interest rate; the exchange rate is very porous and weak due to low purchasing power of the currency. The high interest rate charged by banks discouraged the foreign tourists and weak exchange rate system has made the local naira valueless. Regardless of the situation, easy access to credit must be available to both the host and the guests.

\section{Statement of problem}

The roles of tourism with the collaboration of the financial institutions cannot be overemphasized in the area of channelling funds by the latter to the former to achieve income 
generation, poverty alleviation and creation of employment opportunities. The willingness of banks and non-banks financial institutions to make adequate loans available to develop the tourism sector remains difficulty.

The tourism sector's contribution to economic growth and development has been constrained and deeply hampered by the recent economic recession, high inflation rate, high interest rate, exchange rate volatility etc., in Nigeria. The FIs claim that funds available to the sector has not be judiciously utilized despite the tourism sub-sector lacks adequate financing. It is further believed that many hoteliers have defaulted in loan repayment and channelling the credits differently from the agreed purpose. The unfriendly business environment that is characterized by kidnapping, terrorist groups (Nigerian North -East), social unrest in SouthSouth with Niger-Delta avengers etc., have discouraged millions of tourists to visit obudu catthe ranch in Calabar, Durbar festivals in the north), Yankari Game Reserve in Bauchi, Mambilla Plateau in Taraba State etc.

\section{Research Question}

The under-listed questions require answers in the course of the study;

$\checkmark$ What are the factors influencing financial institutions' participation in tourism in Nigeria?

$\checkmark$ What are the factors responsible for the neglect of tourism development in Nigeria?

$\checkmark$ Is there any relationship between financial institutions and Lagos street carnival?

$\checkmark$ Can tourism promote economic development in Lagos state?

\section{Research Objective}

The main objective of the study is to examine the factors influencing financial institutions' participation in tourism project, considering Lagos street carnival project. The specific objectives include;

To examine the factors that influence financial institutions' participation in tourism sub-sector.

$\checkmark$ To identify the factors that have led to the abandonment of tourism sector development.

$\checkmark$ To determine the existing relationship between financial institutions' and Lagos street carnival project.

$\checkmark$ To examine the extent at which tourism promotes economic development in Lagos.

\section{Research Hypothesis}

It is however hypothesized that;

Ho: There are no significant factors that may influence financial institutions' contribution to tourism sub-sector development in Nigeria.

Ho: There is no relationship between the financing of Lagos carnival project and financial institutions.

\section{LITERATURE REVIEW}

Tourism is characterized with travelling, food or/and drinks or both, accommodation, entertainment, hotels, catering, for leisure, business and other specified/unspecified purposes outside the guests/ strangers usual environment for a period. Tourism sector has created millions of direct/indirect jobs (Abiodun, 2002; WTTC 2013). 
Tourism is not only characterized for consumption of food/ drinks, but also provides platform for tourists to experience and learn the culture, norms, values and beliefs of the host community and enjoy the local delicacies. The sector indirectly contributes and provides awareness about the way and manner the people are blessed with natural endowments in the area of fishery, agriculture, natural attractions, national parks, handicrafts, mining, local food processing process and so on for income and employment generation and achieving national development.

Tourism for decades have contributed to economic opportunity and business expansion in emerging markets and less developed countries to promote foreign direct investment and reduce poverty (UNWTO, 2007). The high number of tourism centres in Nigeria have not drastically reduced poverty and unemployment rate despite various tourism programmes of the government (Okhiria \& Obadeyi, 2015). Abiodun, (2002) review the Nigerian tourism sector: economic contribution, constraints and opportunities, and concludes that there is need to review the rules, regulations and policies that guide the operations of tourism by allowing and increasing the participation of foreign tourists to increase foreign direct investment because of the little contribution of the local tourists. Considering the work of Tunde (2012), "harnessing tourism potentials for sustainable development: A case of Owu water falls in Nigeria" claims that tourism triggers economic development and serves as the largest foreign exchange earners to Nigeria. Considering the present exchange rate USD $\$ 1=\# 475$ (weak purchasing power of the local naira) has made it difficulty and unbearable for local tourists to visit tourist centres during the period the country's economy is trying to come out of recession. The Gross Domestic Product (GDP) is at $-1.8 \%$ in June, 2016 and $-2.06 \%$ in September, same year (CBN, 2016 \& NBS, 2016). Reynolds \& Braithwaite, (2001) in "towards a conceptual framework for wildlife tourism" conclude that tourism for century has always contributed to improve the living standard of people, norms and values; and modernization of tourist attraction centres; and the ecosystem is more protected and developed. The visits of foreign tourists to the tourist centres provides an avenue for cross-country culture associations to enhance economic growth and promote bilateral trade based on mutual understanding between parties. Kehinde \& Adejuwon, (2011) in "financial institutions as catalyst to economic development: the Nigerian experience", claim that financial institutions operate within the financial sector to promote economic development in an economy via the channelling of funds to deficit from the surplus sector, and conclude that there is no informal sector that can thrive without the collaboration with the financial system via financial institutions. Nzotta \& Okereke (2009) claim in "financial deepening and economic development of Nigeria: An empirical investigation" that for informal sector to enjoy financial support from FIs, it requires that the financial sector must be in a healthy condition. But the present challenges facing the FIs in Nigeria is as a result of the economic recession facing the country.

\section{Factors Influencing Financial Institutions Participation in Tourism}

- Foreign direct investment (FDI): It is the control and ownership of investment by any economic agents in a business line from country of origin in another country of interest. It will assist to stimulate foreign tourist investors and creating friendly business environment for economic development. It will further assist international bilateral trade through low import tariff charges on foreign investors to ease trade. The presence of business opportunities in the tourism sub-sector encourage FIs to make credits available for sustainability. It must be noted that this situation will further increase FDI not only in developing countries and emerging markets, but particularly Nigeria (UNCTAD, 2006).

- Mobilization of savings: The large tourism market in Nigeria entices the participation of FIs to stimulate economic growth. FIs ensure increase in the effective and efficient 
economic savings mobilization due to the participation of foreign tourists, because low trends of local tourists' patronization may discourage the FIs' participation in the areas of providing services (i.e. insurance, pension funds, easy access to funds etc.) for tourists. Banks ensure that there are various means of mobilizing economic savings via different bank accounts - savings, current, time deposit account. FIs play an intermediary roles between savers of funds and borrower of funds. The modernization in the financial sector has been able to provide services such as e-banking, internet banking, credit cards, debit cards, electronic fund transfer (EFT), point of sale (POS) etc., to improve cash management and practice, at a reduced transaction cost of service delivery in the tourism sector (Obadeyi, 2014).

\section{Lagos Carnival}

Lagos state is regarded as one of the major commercial cities in Nigeria. The Lagos carnival can be traced to Black Heritage Festival in 70s', which serves as ancestry, and either directly or indirectly linked to Festac '77. Lagos carnival is a street carnival party that is similar to Calabar street carnival party (i.e. largest street carnival in Africa) in South-South Nigeria and returnee emancipados' descendants particularly in Brazil, with a vibrant culture that is beautify with varieties of colored costumes and decorated floats. It is a yearly street carnival party that provides opportunities for Lagos indigenes (Lagosians), non- Lagosians and foreign tourists to celebrate with one another other in dancing and flamboyant artistries. The Lagos carnival has further integrated into different streets within Lagos suburbs, where many streets during Christmas holiday celebrate "street carnivals". The street carnival provides entertainment via singing and drumming in local dialects and dancing in a colourful consumes for people to enjoy and means of promoting cultural heritage. However, funds to finance the street carnivals are generated from individual and number of participatory streets' contributions. The organizing committees for street carnivals within the Lagos suburbs also seek for financial assistance from wealthy people in the society to finance the carnival, but do not approach banks for loans probably due to high interest rate charges, lack of collaterals by the borrowers, possible inability to repay the loans and other conditions may discourage the FIs to provide the funds.

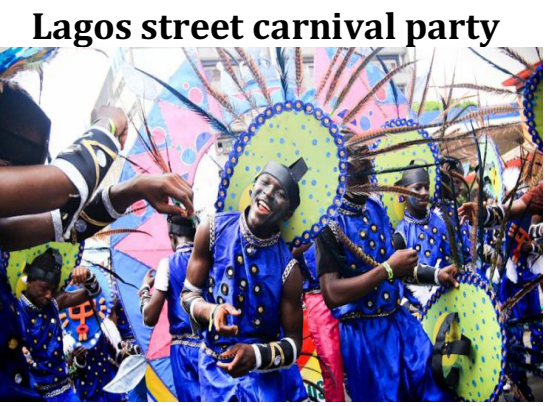

Source: www.lagoscarnival.com; www.lagosblackheritagefestival.com

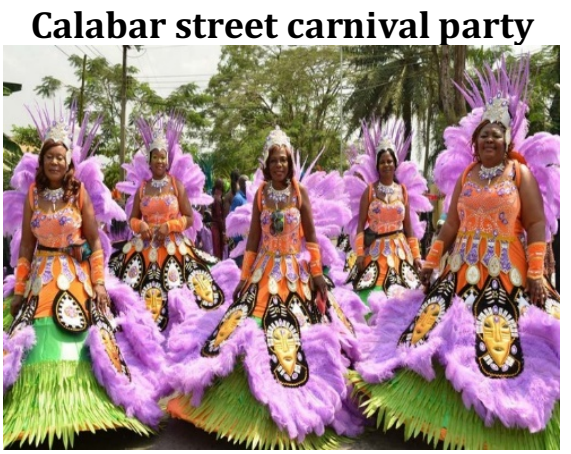




\section{Source: www.carnivalcalabar.com/}

\section{METHODOLOGY}

This section focuses on the research methods and source of data that is adopted in the study. The primary and secondary data are used in the study. Primary data is collected through the structured questionnaire considering the responses of respondents in the study. While the secondary data is collected via referencing, journals, books, newspaper, magazines, internet etc. The questionnaire consists of two sections; section one comprises of the main demographic of the sample; and section two comprises of the questionnaire, which includes the related statements to the study. The questionnaire adopts five point scaled questionnaire (Likert type) consisting of few but relevant questions to the study. In choosing the sample frame, four (4) banks, two (2) insurance companies, and five (5) hotels are selected from Lagos Island (i.e. Tafabalewa square, Tinubu, Itafaji etc.), Ikorodu, Mushin, Oshodi/Isolo and Ikeja (Lagos Mainland) are considered in the study due to business and economic activities that characterize these areas. Having selected these locations is as a resort of the nearness of the researcher to the area by not capturing Epe and badagry. This action is believed to improve the performance of the researcher to gather relevant and timely data for the study.

The number of questionnaires that is administered is two hundred and ten (210). Two hundred and ten (210) questionnaires were administered on banks and insurance companies' customers which lasted for ten (10) days excluding weekends to administer. Eight (8) customers were selected from banks and four (4) from the insurance companies. The purposive (non-probability) sampling method was adopted for banks, hotels and insurance companies; while customers of banks, insurance companies and hotels were randomly chosen. The random sampling helped to ensure an unbiased sample population, by allowing all the respondents to have equal chance of being selected and well represented. One hundred and forty (140) questionnaires were returned. It however implies that $66.7 \%$ are correctly filled and returned. It is about forty-three (43) questionnaires that are wrongly filled, while twentyseven are incomplete and invalid that is, $33.3 \%$ of the questionnaires were not returned, a very low number of the questionnaires were completed immediately, while larger proportions were collected at a later date. Prior to the field work, a pilot study was conducted.

\section{RESULTS}

The purpose of the research work is to determine the factors that influence FIs' participation in Tourism project; case of Lagos street carnival. Descriptive statistics was adopted to analyse frequencies and percentages trends. However, one hundred and forty (140) respondents were simply considered. The A Z- score statistics was employed in testing the hypothesis. Symbolically representation of $Z_{0.995}-$ Score statistics was given as $Z=X-\mu / \delta \sqrt{N}$. Where $Z$ was the $\mathrm{Z}_{0.995}$ - score value, $\mathrm{X}$ was sample mean, $\mu$ was the population mean and $\delta$ was the standard error of the mean. The test has adopted 99\% confidence level i.e., (1\%) level of significance. Charles \& Corrine (2010) and Murray \& Larry, (2011) claimed that the higher value of the mean score, showed that the respondents agreed far better with the statement under consideration in the study. Newman, (2009) opined that testing the significance level of the z-score explained the testing of the null hypothesis (Ho) against alternative hypothesis (Hi), either 'Hi' was stated or not. The intervals were considered because it was the range (i.e. between lower and upper limits) of values within which the population parameter was thought to lie. A one-sided alternative hypothesis would be appropriate when testing the null hypothesis that one product was better than another. The rules stated that if the null hypothesis was true i.e. the zones and sample means did not lie within population means at 0.05 significant level, the null hypothesis was otherwise accepted, if not we accept the alternative hypothesis (Oyesiku \& Omitogun, 1999; Newman, 2009; Charles \& Corrie, 2010). 
To have tested the hypothesis in Question 1 - 4, which have six (6) statements each; the results were explained as follows;

Table I below showed the mean scores of factors that influence FIs participation in tourism sub-sector. Having examined the statements in the table, 'To increase savings mobilization' (4.21), it was ranked first; 'Reducing limited access to funds in the tourism sub-sector,' (4.11), it was ranked second; 'Increase foreign direct investment (FDI),' (3.84) was ranked third; 'Provision of luxury activities,' (3.66), which was ranked fourth; 'To promote and develop infrastructure (power, roads, transport etc.)' (3.57), it was ranked fifth; 'Increase in the contribution of government revenue,' (3.32), it was ranked sixth; and with overall value, (22.71).

Table II below considered factors that led to abandonment of tourism sector development; 'Lack of adequate provision of Finance by FIs., (4.05) was ranked first; 'Over-dependence on crude oil,' (3.89) was ranked second; 'Ethnical differences in beliefs and culture,' (3.56) was ranked third; 'Insecurity (Kidnapping, hijacking of airplanes, terrorists attacks etc.),' (3.49), that was ranked fourth; 'Socio-economic and political challenges,' (3.31) was ranked fifth; 'Inconsistent government policies via agencies, departments and ministries,' (3.02), that was ranked sixth; and with overall, (21.32).

Table III below showed the mean scores of determining the existing relationship between financial institutions and Lagos street carnival project. Having examined the statements in the same table, 'Building business opportunities' (3.74), it was ranked first; 'Increase in the participation of foreign tourists,' (3.61), was ranked second; 'Provision of conducive business environment,' (3.55) was ranked third; 'Establishing institutional capacity,' (3.36), was ranked fourth; 'Healthy competition,' (3.10), was ranked fifth; 'Public / Private Sponsorship,' (3.04), was ranked sixth; and 'overall' (20.40).

Table IV below showed the mean scores of determining the extent at which tourism promotes economic development in Lagos. Having examined the statements in the same table, 'Increase in income and employment generation' (4.14), it was ranked first; 'Alleviation of poverty,' (4.02), was ranked second; 'Helps to promote cultural standard,' (3.65) was ranked third; 'Provision of funds for infrastructural development,' (3.45), was ranked fourth; 'Promoting business opportunities,' (3.39), was ranked fifth; 'High demand for local produce,' (3.13), was ranked sixth; and 'overall' (21.76).

Table V revealed that Q1 showed that sample mean equals 4.03500, standard deviation equals 0.03750 , standard error of the mean equals 0.00320 and population mean ranges from 4.0267 to 4.0433, the z-score @ 2.58, the relationship between variables was significant. Also Q2 revealed that sample means equals 3.90750, Standard deviation equals 0.02678, Standard error of the Mean equals 0.00226, population mean ranged from 3.9017 to 3.9133, Z-score @ 2.58 and the existing relationship between variables was also significant. Q3 showed that sample mean equals 3.6000, standard deviation equals 0.00074 , standard error of the mean equals 0.00006 and population mean ranges from 3.5999 to 3.6002, the z-score @ 2.58, the relationship between variables was significant. Q4 showed that sample mean equals 3.53500, standard deviation equals 0.00040 , standard error of the mean equals 0.00003 and population mean ranges from 3.5349 to 3.5351, the z-score @ 2.58, the relationship between variables was significant. Q5 and Q6 showed that sample mean equals 3.34250, Standard deviation equals 0.01720, Standard error of the Mean equals 0.00145, population mean ranged from 3.3388 to 3.3462 , Z-score @ 2.58 and the existing relationship between variables was significant; sample mean equals 3.12750, Standard deviation equals 0.03200, Standard error of 
the Mean equals 0.0027, population mean ranged from 3.1205 to 3.1345, Z-score @ 2.58 and the existing relationship between variables was significant respectively.

Therefore, there were significant factors that influence financial institutions' contribution to tourism sub-sector development in Nigeria; and there exist relationship between the financing of Lagos carnival project and financial institutions. Rejecting the null hypotheses helped us to further understand that Public/private partnership initiatives have increased the level of promoting and attracting investment via financial support from financial institutions and multi-national corporate agencies to make the carnival a success. Tourism sector has assisted to strengthen the market intermediaries, creating job opportunities and meeting tourists' demands, e.g., travel experience.

Table I: Perceptions of factors that influence FIs participation in tourism sub-sector.

\begin{tabular}{|l|c|c|}
\hline Variables & Mean & Rank \\
\hline $\begin{array}{l}\text { Factors that influence FIs participation in tourism sub-sector } \\
\text { (Overall) }\end{array}$ & 22.71 & \\
\hline Reducing limited access to funds in the tourism sub-sector & 4.11 & 2 \\
\hline $\begin{array}{l}\text { To promote and develop infrastructure (power, roads, transport } \\
\text { etc.) }\end{array}$ & 3.57 & 5 \\
\hline Increase foreign direct investment (FDI) & 3.84 & 4 \\
\hline Increase in the contribution of government revenue & 3.32 & 6 \\
\hline Provision of luxury activities & 3.66 & 3 \\
\hline To increase savings mobilization & 4.21 & 1 \\
\hline
\end{tabular}

Source: Researchers' compilation 2017

Table II: Perceptions of identifying factors that led to abandonment of tourism sector development

\begin{tabular}{|c|c|c|}
\hline Variables & Mean & Rank \\
\hline $\begin{array}{l}\text { Factors that led to abandonment of tourism sector development } \\
\text { (overall) }\end{array}$ & 21.32 & \\
\hline Insecurity (Kidnapping, hijacking of airplanes, terrorists attacks etc.) & 3.49 & 4 \\
\hline $\begin{array}{l}\text { Inconsistent government policies via agencies, departments and } \\
\text { ministries }\end{array}$ & 3.02 & 6 \\
\hline Lack of adequate provision of Finance by FIs. & 4.05 & 1 \\
\hline Over-dependence on crude oil & 3.89 & 2 \\
\hline Ethnical differences in beliefs and culture & 3.56 & 3 \\
\hline Socio-economic and political challenges & 3.31 & 5 \\
\hline
\end{tabular}

Source: Researchers' compilation 2017

Table III: Perceptions of Examining of determining the existing relationship between financial institutions and Lagos street carnival project

\begin{tabular}{|l|c|c|}
\hline Variables & Mean & Rank \\
\hline $\begin{array}{l}\text { Relationship between financial institutions and Lagos street } \\
\text { carnival project (overall) }\end{array}$ & 20.40 & \\
\hline Provision of conducive business environment & 3.55 & 3 \\
\hline Increase in the participation of foreign tourists & 3.61 & 2 \\
\hline Building business opportunities & 3.74 & 1 \\
\hline Establishing institutional capacity & 3.36 & 4 \\
\hline Healthy competition & 3.10 & 5 \\
\hline Public / Private Sponsorship & 3.04 & 6 \\
\hline
\end{tabular}

Source: Researchers' compilation 2017 
Table IV: Perceptions of determining the extent at which tourism promotes economic development in Lagos.

\begin{tabular}{|c|c|c|}
\hline Variables & Mean & Rank \\
\hline $\begin{array}{l}\text { Determining the extent at which tourism promotes economic } \\
\text { development in Lagos (overall) }\end{array}$ & 21.76 & \\
\hline Increase in income and employment generation & 4.14 & 1 \\
\hline Helps to promote cultural standard & 3.63 & 3 \\
\hline Promoting business opportunities & 3.39 & 5 \\
\hline Provision of funds for infrastructural development & 3.45 & 4 \\
\hline High demand for local produce & 3.13 & 6 \\
\hline Alleviation of poverty & 4.02 & 2 \\
\hline
\end{tabular}

Source: Researcher's compilation 2017

Table V: Mean score, Standard Deviation, Z- Score and the Significance of the Variables

\begin{tabular}{|c|c|c|c|c|c|c|}
\hline Variable & $\begin{array}{c}\text { Sample } \\
\text { Mean }(\mathrm{x})\end{array}$ & $\begin{array}{c}\text { Standard } \\
\text { Deviation }\end{array}$ & $\begin{array}{c}\text { Standard } \\
\text { Error }(\mathrm{x})\end{array}$ & $\begin{array}{c}\text { Population Mean } \\
(\mu)\end{array}$ & $\begin{array}{c}\text { Z-score } \\
@ ~ 0.01\end{array}$ & Decision \\
\hline Q1 & 4.03500 & 0.03750 & 0.00320 & $4.0267-4.0433$ & 2.58 & Significant \\
\hline Q2 & 3.90750 & 0.02678 & 0.00226 & $3.9017-3.9133$ & 2.58 & Significant \\
\hline Q3 & 3.60000 & 0.00074 & 0.00006 & $3.5999-3.6002$ & 2.58 & Significant \\
\hline Q4 & 3.53500 & 0.00040 & 0.00003 & $3.5349-3.5351$ & 2.58 & Significant \\
\hline Q5 & 3.34250 & 0.01720 & 0.00145 & $3.3388-3.3462$ & 2.58 & Significant \\
\hline Q6 & 3.12750 & 0.03200 & 0.00270 & $3.1205-3.1345$ & 2.58 & Significant \\
\hline
\end{tabular}

Source: Researchers' compilation 2017

$\mathrm{Y}$ is a dependent variable, which is a function of independent variable, $\mathrm{X} ; \lambda=$ intercept; $\delta=$ slope / coefficients, and $\mu$ is stochastic variable/ an error term as stated in equation 1 below. The model below is adopted for the simple regression analysis as stated thus:

$$
\begin{array}{r}
\mathrm{Y}=\lambda+\delta_{1} \mathrm{X}+\mu- \\
\mathrm{TP}=\lambda+\delta_{0} \mathrm{AF}+\delta_{1} \mathrm{IP}+\delta_{2} \mathrm{SM}+\delta_{3} \mathrm{CB}+\mu
\end{array}
$$

Where

$\mathrm{TP}=$ Tourism participation; $\mathrm{AF}=$ Access to funds; $\mathrm{IP}=$ Infrastructural provisions; Savings mobilisation $=\mathrm{SM}$; Cultural beliefs

$\lambda=$ Intercept; $\delta_{0}, \delta_{1}, \delta_{2} \& \delta_{3}=$ coefficients;

$\mu=$ an error term

Equation 2 above shall test the impact of each of the explanatory variables (AF, IP, SM, and CB) on TP in Lagos.

$$
\mathrm{TP}=0.425+0.152 \mathrm{AF}+0.374 \mathrm{IP}+0.269 \mathrm{SM}+0.241 \mathrm{CB}
$$

Table VI. Regression Analysis

\begin{tabular}{|c|c|c|c|c|}
\hline \multicolumn{5}{|c|}{ Model Summary } \\
\hline Model & $\mathrm{R}$ & R Square & $\begin{array}{c}\text { Adjusted R } \\
\text { Square }\end{array}$ & $\begin{array}{c}\text { Std. Error of } \\
\text { the Estimate }\end{array}$ \\
\hline 1 & $.749 \mathrm{a}$ & .561 & .548 & .461 \\
\hline a. & Predictors: (Constant), AF, IP, SM, CB. \\
\hline b. Dependent: TP
\end{tabular}

Source: Researchers' compilation 2017 
From table VI above, the value of R Square (0.561), measuring goodness of fit) is high and it shows that the regression model is fit. The adjusted R Square (0.548) indicates that the model; access to funds - AF; infrastructure provision -IP; savings mobilisation - SM and cultural beliefs - CB explain $56.1 \%$ of the variation of factors influencing financial institutions participation in tourism, particularly Lagos street carnival.

Table VII. ANOVA RESULT

\begin{tabular}{|l|l|c|c|c|c|c|}
\hline \multicolumn{7}{|l|}{ ANOVA $^{\text {a }}$} \\
\hline Model & Sum of Squares & Df & Mean Square & F & Sig. \\
\hline \multirow{3}{*}{1} & Regression & 189.46 & 36 & 5.263 & 4.56 & $.000^{\mathrm{b}}$ \\
\cline { 2 - 7 } & Residual & 120.12 & 104 & 1.115 & & \\
\cline { 2 - 7 } & Total & 309.58 & 140 & & & \\
\hline \multicolumn{2}{|l}{ a. Predictors: (Constant), AF, IP, SM, CB. } \\
\hline
\end{tabular}

\section{Source: Researchers' compilation 2017}

To assess the statistical significance of the results of the $\mathrm{R}$ Square explained the above table. It is necessary to look in the above ANOVA table. From the table VII, the F-Statistics (4.56) is high and the P-value (0.000) is less than 0.05 which all together indicates that overall impact of the independent variables on the dependent variable is significant.

Table VIII. COEFFICIENT RESULT

\begin{tabular}{|c|c|c|c|c|c|c|}
\hline \multicolumn{7}{|c|}{ Coefficients $^{a}$} \\
\hline \multirow{2}{*}{\multicolumn{2}{|c|}{ Model }} & \multicolumn{2}{|c|}{$\begin{array}{l}\text { Unstandardized } \\
\text { Coefficients }\end{array}$} & \multirow{2}{*}{$\begin{array}{c}\begin{array}{c}\text { Standardized } \\
\text { Coefficients }\end{array} \\
\text { Beta } \\
\end{array}$} & \multirow[t]{2}{*}{$\mathrm{T}$} & \multirow[t]{2}{*}{ Sig. } \\
\hline & & B & Std. Error & & & \\
\hline \multirow[t]{5}{*}{1} & (Constant) & .425 & .061 & & 6.967 & .000 \\
\hline & $\mathrm{AF}$ & .152 & .046 & .021 & 3.304 & .000 \\
\hline & IP & .374 & .042 & .039 & 8.905 & .000 \\
\hline & SM & .269 & .038 & .115 & 7.079 & .000 \\
\hline & CB & .241 & .057 & .124 & 4.228 & .000 \\
\hline \multicolumn{7}{|c|}{ a. Predictors: (Constant), AF, IP, SM, CB. } \\
\hline & t Vari & & & & & \\
\hline
\end{tabular}

\section{Source: Researchers' compilation 2017}

The table VIII above shows the magnitude of the impact of each of the explanatory variables on the dependent variable. Looking at the column titled "Beta" in the table, the Beta coefficient value for access to funds, infrastructural provision, savings mobilisation and cultural beliefs are $0.152,0.374,0.269$ and 0.241 respectively.

All the coefficients of explanatory variables are positive i.e. $>0$. This conforms to a priori expectation of a positive relationship between the dependent and explanatory variable as shown in equation 3.

From table VIII, the coefficient of AF is statistically significant even at 1 per cent level of significance. This is because the t-statistic for the coefficient of AF is 3.304 i.e. high and the probability of error is 0.000 . The coefficient of IP is statistically significant at 1 per cent level of significance. This is because the t-statistic for the coefficient of IP is 8.905 i.e. high and the probability of error is 0.000 . Also, the coefficient of SM is statistically significant at 1 per cent level of significance. This is because the t-statistic for the coefficient of SM is 7.079 i.e. high and the probability of error is 0.000 . It must also be noted that, the coefficient of CB is statistically significant at 1 per cent level of significance. This is because the t-statistic for the coefficient of CB is 4.228 i.e. high and the probability of error is 0.000 .The overall statistic is significant at 1 
per cent level of significance; since F-statistic of 4.56 is very high and the associated probability of error 0.000 is very low as shown in table VII.

\section{FINDINGS}

- Access to funds, infrastructural provision, mobilisation of savings and promoting cultural beliefs have influence and significant relevance on financial institutions participation in tourism in Lagos. This implies that these factors and others can influence FIs in the promotion and development of street carnivals in Lagos.

- The Lagos street carnival is faced with various challenges such as insecurity, low number of foreign tourists, exchange rate volatility, economic recession, lack of adequate funds and insufficient number of FIs to sponsor the festival.

- Tourism creates the platform for more employment opportunities in Lagos.

- It creates avenue for the showcase of the indigenes' cultural heritage; which is beautify with variety of magnificent colours.

\section{CONCLUSION}

The study aimed to examine factors influencing financial institutions' participation in tourism project: case of Lagos street carnival. The study concluded that street carnival has not become popular in Nigeria unlike countries like, Brazil (Rio Carnival, Rio de Janeiro), Canada (Toronto International Carnival Parade), UK (Notting- Hill Carnival), Trinidad and Tobago (Trinidad and Tobago Carnival, Port of Spain), Japan (Asakusa Samba Carnival, Tokyo), Jamaica (Bacchanal Jamaica, Kingston), Bolivia (Carnival of Oruro, Oruro), United States (Mardi Gras, New Orleans), etc. The study discovered that the two major street carnivals in Nigeria is Lagos and Calabar Street carnivals. Therefore other states in the country can come up with street carnivals to promote our religion, folklores, tradition, norms, values, beliefs of the people and to help develop the tourism sub-sector. The carnival requires a lot of funds to finance hence, financial institutions need to efficiently play the intermediation roles of channeling funds to more street carnivals for promoting our ethnical differences but in unity in a global stage via the collaboration with Federal Ministry of Culture and Tourism (FMCT) possibly responsible for policy formulation. The paper also recommends that Nigerian Tourism Development Corporation (NTDC), should not only be saddled with the responsibility of a regulator, but come up with policies to reform the tourism sector in order to meet-up with the international acceptable standards.

\section{References}

Akanji, 0. 0. (2006). Microfinance as a Strategy for Poverty Reduction. Central Bank of Nigeria Economic and Financial Review, 39 (4).

Abiodun, B. (2002). The Nigerian Tourism Sector: Economic Contribution, Constraints and Opportunities. Journal of Hospitality Financial Management, 10(1), 72 -78.

CBN (2016). Central Bank of Nigeria Communique No 107 of the Monetary Policy Committee Meeting of Monday and Tuesday 23rd and 24th May.

Kehinde, J.S., \& Adejuwon, K. D. (2011). Financial Institutions as Catalyst to Economic Development: The Nigerian Experience. European Journal of Humanities and Social Sciences 8(1), 324 - 329.

Murray, S., \& Larry, S., (2011). Statistics (4th ed.). New York: Mc-Graw Hill Companies Inc.

Newman, J. (2009). Fundamentals of Statistical Analysis (2nd ed.). New York: Row Publishers.

Nzotta, S.M., \& Okereke, E. J. (2009). Financial Deepening and Economic Development of Nigeria: An Empirical Investigation. African Journal of Accounting, Economics, Finance and Banking Research, 5(5), 53 -58.

Obadeyi, J. A. (2014). The Effect of Financial Reforms on Banking Performance in Emerging Market: Nigerian Experience. Research Journal of Finance and Accounting, 5(23), 46-53. 
Okhiria, A.O., \& Obadeyi, J. A. (2015). Terrorism, a Global Phenomenon Threat to Banking and Tourism Sectors in Nigeria: A True Story. European International Journal of Science and Humanities. 1(5), 35- 42.

Oyesiku, O., \& Omitogun, O., (1999). Statistics for Social and Management Sciences. Lagos: Higher Education Books Publishers (HEBP).

Reynolds, P. \& Braithwaite, B., 2001. Towards a conceptual framework for wildlife tourism. Tourism Management. 22(1), 31-42

Tunde, A. M., 2012. Harnessing tourism potentials for sustainable development: A case of Owu water falls in Nigeria. Clarion University of Pennsylvania, Clarion, Pennsylvania. Journal of Sustainable Development in Africa 14(1), 119-126.

UNCTAD (2006): World Investment Report, United Nations, New York.

United Nations World Tourism Organizations (UNWTO). 2007. Market intelligence and promotion department, data provided by Diottalevi, Marina, Chief, Cultural, Social and Ethical Aspects of Tourism, 24th September.

World Travel and Tourism Council (WTTC). 2013. Travel \& Tourism Economic Impact 2013 Sub Saharan Africa, WTTC, London, U.K.

www.lagoscarnival.com

www.lagosblackheritagefestival.com 